\title{
Financial Distress and Highway Infrastructure Delays
}

\section{Abstract:}

Purpose: In developing countries, delays in highway infrastructure projects caused by financial distress-related factors threaten the construction industry's capacity to contribute optimally to economic development. Against this backdrop, this paper determines factors contributing to financial distress and develops a conceptual framework to illustrate the relationship between financial distress and project delay.

Design: A questionnaire survey collected data on factors that contributed to financial distress and delays in highway infrastructure delivery. 78 responses were obtained and factor analysis revealed that factors associated with payment, project financing, cash flow, economic issues, project planning and cost control influenced project delays.

Findings: The research identifies the importance of efficient public and private policies to engender financial sustainability amongst construction firms in developing countries.

Originality: This work presents the first research of its kind and strives to engender wider academic debate and renewed economic development in some of the world's most impoverished nations.

Keywords: Ghana, infrastructure, financial distress, delays, road construction,

\section{Introduction}

The infrastructure gap in developing economies is circa US\$31 billion per year and culminates in construction and civil engineering project delays (Foster and Briceño-Garmendia, 2009). Consequently, economic development and national productivity performance has been stifled (De 
Gregorio, 2015). Within Ghana, successive post-independence governments have initiated and implemented diverse and ambitious infrastructure projects to boost infrastructural and economic development (Badu and Owusu-Manu, 2011). For instance, the Accra-Tema Motorway (Anaman, 2006) and the George W. Bush Highway. Yet despite this firm government commitment, many major projects are delayed and in-turn result in cost escalations. In Nigeria for example, $70 \%$ of projects suffer delays, the causes of which are myriad (Odeyinka and Yusif, 1997). Despite its importance, limited research has been undertaken to determine the factors that contribute to financial distress in construction project delivery, and particularly highway construction. Therefore, this paper aims to determine the underlying factors contributing to financial distress of construction firms completing highways projects and investigate the interconnections between these factors and project delays. A primary objective being to stimulate fresh thinking amongst industry stakeholders including government policy-makers and construction organizations (including consultants, contractors, client and suppliers) on how to remove delay-associated problems and improve the construction supply-chain (Badu and Owusu-Manu, 2010). The research also strives to engender wider academic debate and stimulate renewed economic development in some of the world's most impoverished nations.

\section{Financial Distress}

Financial distress represents inadequate liquidity and consequential difficulties of meeting financial obligations promptly (Maksimovic and Phillips, 1998). According to Karl (2002), financial distress is a long-term process which negatively impacts upon a company's capital structure, investment policies performance and business survival. Financial distress derives primarily from high gearing or following a highly distressing event such as major fraud (Tsai, 2014). Numerous factors cause financial distress, for example: high interest rates chargeable on loans; lack of regular cash flow 
forecasting; low markup/ profit margins; poor credit arrangement with creditors and financiers; and difficulty in loan accessibility. Memba and Job (2013) attribute financial distress to two dichotomous groupings of endogenous and exogenous variables. Endogenous variables are firm specific and include: inadequacy of capital; shortage of skilled manpower; poor accounting records; and poor internal management. Ameriks et al., (2003) revealed human-behavioral factors could also impact upon financial distress including managers' characteristics, which manifest in their capacity for self-control, planning and patience. In contrast, exogenous variables are external to the company and transcend all firms in a market irrespective of their individual characteristics (e.g. company size, type and industry sector operated within). Exogenous risk factors are sensitive to prevailing economic change, competitive pressures, government constraints, social alterations and technological change. Figure 1 provides a conceptual framework of the internal and external risk triggers of financial distress that have been derived from extant literature (refer to Table 1). Within this framework, endogenous and exogenous risk triggers are mapped to a description of the broad range of firms affected in an economy. Based on the above, it is hypothesized that:

$H_{o}:$ Highway project delays are not positively related to the financial distress factors indicated in Table 1 below.

\section{Research Approach}

A deductive methodological approach was adopted using a quantitative survey design based upon an extensive extant literature review. From an operational perspective, a three stage process was adopted to fulfill the research aims and objectives. During stage one, (a) descriptive statistics were analyzed and (b) hypothesis testing undertaken using the Chi-Square statistic. Stage two then 
proceeded to conduct (c) factor analysis once preliminary checks had been undertaken prior to developing the conceptual model in stage three.

A questionnaire that was divided into five sections and contained both open and closed questions was distributed by surface and electronic mail using a snowball sampling technique. 100 questionnaires were sent to small to medium enterprise (SMEs) highway contractors operating within Accra and Kumasi metropolitan areas in Ghana because $75 \%$ of SME road construction firms are located within these two cities (Badu et al. 2011). Respondents' perceptions and opinions on financial distress and delays in highway construction were specifically sought. Section one accrued information on the type of SME construction firm while section two sought to uncover the respondents' years of experience in highway construction. Section three sampled respondents' opinions on the relationship between financial distress related factors and project delay, while section four gave respondents an opportunity to rate 20 financial distress related variables (previously identified within the extant literature - refer to Table 1). Section five afforded respondents with an opportunity to rate the importance of mitigation measures. Question responses were measured with a five point Likert item scale ranging from 1 to 5 . A high $78 \%$ response rate was achieved primarily due to follow-up telephone calls made to targeted respondents.

Factor Analysis analysis was adopted to uncover potential variables measuring aspects of the same underlying dimensions. To determine sample size, the rule of thumb established by Adadzie (2007) was adopted, namely that: factor analysis is reliable regardless of the sample size if the factor loadings are more than four with loading greater than 0.6 (c.f. Ahadzie, 2007). For this study, the factor loadings and other tests conducted gave the KMO test of 0.705 suggesting the reliability of 
factor analysis. The Chi Square Test of Independence was adopted for hypothesis testing because data collected was mainly ordinal.

\section{DATA ANALYSIS}

Table 2 exhibits limited data variability in terms of the standard deviation and is an acceptable reflection of the population. For instance, almost all variables have sample mean values $>$ the accepted population mean of 3.5 with standard deviations and standard errors $<1.0$. This finding suggests that financial distress factors obtained from the extant literature are applicable to this study. Chi-square test results confirm the null hypotheses that financial distress variables do not contribute to project delays and is therefore rejected (Table 3). From Table 3, for each of the independent variables of financial distress for each of the independent variables, $\chi^{2}$ cal $>\chi^{2} \alpha$ at $p<$ 0.05 in all cases of the independent variables, the null hypothesis can be rejected. Logically, it can be concluded that highway construction project delays are positively related to the financial distress factors indicated in Table 3 .

\section{Factor Analysis}

The adequacy of the sample size was confirmed by the Kaiser-Meyer-Olkin (KMO) which recorded a value of 0.705 . Thus, Principal Component Analysis should yield distinct and reliable factors. Bartlett's Test checked for relationships between variables by testing the null hypothesis that the original correlation matrix (R-matrix) is an identity matrix. As the R-matrix is not an identity matrix, it can be concluded that: i) there are no difficulties in determining the unique contribution of the variables to a factor; and ii) some relationships exist between the variables that can be analyzed. 
The communality of the variable represents the proportion of variance explained by the common factors and can range from 0 to 1, where: 0 implies that common factors do not explain any of the variance; and 1 implies that all the variance is explained by common factors (Mathur et al., 2013). Table 4 reveals that the average of variable communalities after extraction was above 0.60 suggesting that the extracted components satisfactorily represent financial distress factors.

Six financial distress principal components were extracted from the twenty causes of project delays based on an eigenvalue greater than 1 (refer to Table 4). These are: component one $(C 1)$ payment issues $\left(21.38 \%^{1}\right)$; component two (C2) project financing issues $(15.40 \%)$; component three $(C 3)$ cash flow issues (12.39\%); component four (C4) economic issues (9.45\%); component five (C5) political influence (6.12\%); and component six (C6) cost control issues (5.99\%). All six extracted principal components cumulatively explained $70.86 \%$ of the variation in the data, which is greater than a minimum of $50 \%$ required by the cumulative proportion of variance criterion (Comrey and Lee, 1992). The Guttman-Kaiser rule suggests that only those factors with an eigenvalue larger than 1 should be retained (Sá et al., 2014), whilst the Cattell scree test suggests that all further components (after the one starting at the elbow) should not be included (Figure 2). The scree plot depicts the relationship between the various components and their corresponding eigenvalues drops below an eigenvalue 1 after the sixth component. Principal component analysis (with varimax rotation) was then conducted (refer to Tables 5 and 6). The eigenvalue and factor loadings were set at conventional high values of 1.0 and 0.50 respectively.

\footnotetext{
${ }^{1}$ This percentage represents the total variance explained by a component or the remaining variance not explained by previous components cited.
} 


\section{Discussion of Results}

\section{Profile of Respondents}

Participating firms included sole proprietorship (28.2\%), partnership (23.1\%) and limited liability companies (48.7\%) (refer to Table 7). Practice knowledge of highway construction amongst the sample was varied but over $80 \%$ had accrued six or more years' experience on such projects. Figure 3 identifies the relationship between exogenous and endogenous factors that emerged from the analysis and illustrates they work in unison to exert financial distress. These factors are now discussed.

\section{Payment Issues $(C 1)$}

Five variables loaded onto this component were: i) contractor's invalid claim; ii) withholding of payment by client; iii) bureaucracy in honoring payment certificates; iv) inaccuracies in valuations for work done by consultants; and v) underestimation of project cost. Zack (1993) observed that payment issues may arise from disputes attributable to 'claimsmanship', which represents lack of fairness in the approach adopted by contract administrators when assessing claims. This adversarial approach reduces transparency and creates mistrust/ unnecessary tension between contract parties. When disputes escalate, a rippling effect further exacerbates the contractor's finance because of invalid claims made by them; the latter may arise from inaccuracies in valuations for work done and/ or underestimation of project cost. Inaccuracies in valuation and underestimation of project cost leads to cost deviations which are systematic and/ or specific in cause. Systematic causes such as macroeconomic perturbations can complicate the forecasting of project costs and valuations hence, subjecting claims to further uncertainty. For instance, during the past 3 years inflation rates have increased year-on-year from $8.73 \%$ in 2012 to $8.8 \%$ in 2013 and $14.7 \%$ in 2014. Cost estimates quoted in 2012 fell considerably below 2014 estimates, making original quotations 
inaccurate and unreliable. Employing robust methods for forecasting macroeconomic conditions could alleviate risks and uncertainty; however, Ghanaian contractors lack the expertise for modelling such trends and cannot afford costly consultants.

The unofficial dollarization of Ghana's economy has led to incremental cost increases of projects due to the consistent depreciation of Ghana's currency (the 'Cedi') against other major trading currencies. For example, the US dollar appreciated by over $50 \%$ against the Ghana cedi between 2012 and 2014 (US\$1 = GHS1.924 and GHS2.70 respectively). Consequently, contractors' claims may not necessarily be invalid but inadequate client planning may lead to financial distress contagion i.e. the transmission of financial distress conditions of debtors to creditors. Contractors' in-turn face a moral dilemma of either passing on the debts/ liabilities onto subcontractors, suppliers and creditors or risk insolvency. Typical claim violations include procedural, typographical or deliberate/ fraudulent errors. Other causes of delay may include: construction defects; disputed works; and failure to comply with any material provisions stated within the contract. A more serious situation arises when the claimant deliberate underestimates costs in order to secure project approval (Ahmed et al., 2003). Thus, project cost overruns delay project delivery because securing extra sources funds to continue the works become problematic.

\section{Project Financing Issues (C2)}

Four variables loaded onto the second component were: i) high interest rate; ii) poor credit arrangement; iii) difficulty in loan accessibility; and iv) insolvency. Project financing encapsulates difficulties in sourcing both project finance and working capital. A firm's ability to obtain credit varies widely based on the perceived loan risk and is consequently dependent on financial economies of scale. This advantage is rarely enjoyed in Ghana's construction industry, which is 
dominated by SMEs that account for approximately $90 \%$ of all construction firms (Wells, 2007). The major challenge facing SMEs is the inability to satisfy the conventional five Cs lending criteria utilized in credit analysis; namely: i) lack of credit history ('character'); ii) inadequate 'collateral'; iii) inadequate equity 'capital' on their balance sheets; iv) inadequate 'capacity'; and v) adverse macroeconomic 'conditions'. The underlying problem is asymmetric information about these SME construction firms, which is largely attributed to poor accounting standards in Ghana's construction industry. Accounting malfeasance generates asset-liability maturity gapping events leading to insolvency and prolonged project fundraising processes that create project delays.

\section{Cash Flow Issues (C3)}

The third component consists of three variables, namely: i) divulging funds; ii) fraudulent practices; and iii) lack of cash flow forecasting. Liquidity is a company's lifeblood and facilitates new investments, helps to start-up new projects and ensures that existing projects are delivered on schedule. Regular cash flow forecasting leads to early identification of latent cash flow problems. Robust cash flow forecasting is imperative but most Ghanaian contractors are unskilled and unable to perform complex models required to produce reliable forecasts in Ghana's economically volatile economy. A mismatch in assets and liability may therefore arise and consequently delay projects.

Divulging funds and fraudulent practice are inextricably linked because often project funds in Ghana are channeled into other areas of business operations or personal usage. Fraudulent practices are commonplace across West Africa and in Nigeria, they are the second most important factor affecting construction delays. For SME contractors, fraud is financially disastrous as it denies them the liquidity needed to complete works. 


\section{Economic issues $(C 4)$}

The fourth component comprises: i) high tax allocation; and ii) unstable inflation rates. SMEs are more likely to face higher tax brackets than larger construction firms (Tanco et al., 2015). Tax deductibles are benefits enjoyed for leveraging as construed from the Trade-Off Theory of capital structure; yet, SMEs are unable to access financial economies of scale and so lose out on allowable tax deductions. Tax deductions and low corporate tax payment could be maximized by companies with low equity-to-debt ratios. For instance, $70 \%$ equity-to-debt ratio indicates that interest payments on $70 \%$ of total return is tax deductible compared with lesser ratios. In other words, SMEs pay high taxes on their substantial sweat equity contributed towards the delivery of construction projects due to high equity-to-debt ratios. High tax payments reduce profitability and could delay the delivery of subsequent larger projects. High inflation leads to underestimation of project cost and inaccurate valuations especially in the absence of a reliable and robust project cost model. This problem is further compounded in capital scarce economies during periods of austerity because payment for unplanned incremental costs claims due to inflation may be delayed. Subsequently, contractors may be financially distressed - leading to project delays.

\section{Political influence (C5)}

The three variables loaded onto the fifth factor are: i) budget allocation not made by clients; ii) contractor handling many projects at the same time; and iii) low profit margins. The Ghanaian government is the industry's major client yet project budgets are often inadequate due to capital constrains and political pressures. Examples include the neglected affordable housing schemes and the University of Health and Allied Sciences in the Volta region. These white elephants create uncertainty about the timing and adequacy of payment of claims, making it difficult for contractors to balance assets and liabilities. The proliferation of SME construction firms in Ghana is 
orchestrated by the desire of company directors to exploit political linkage and cronyism thus avoiding logistical and capital constraints confronting them. Cronyism and political patronage of 'favored contractors' by Government officials is common place in developing economies and prevents a free market from operating (Salleh and Ahmad, 2012). Inadequate resources delay project execution that may subsequently be re-awarded after a significant time lapse - thus incurring further cost and opportunities for corruption. To combat political favoritism, other contractors underestimate project costs to win procurement bids which in turn reduces profit margins and leads to project failure or contractor bankruptcy.

\section{Cost Control Issues (C6)}

The two variables that loaded onto the sixth component are: i) high overhead cost; and ii) capital lockup. Businesses must control and manage overhead costs to improve their financial situation (Cilensek, 1991). Overheads are indirect to the profit generation capacity of projects but imperative for the operation of construction firms and include rents, professional fees, interest, insurance, taxes and utilities. Capital lock-up could emanate from high overheads and delays in claim payment on previous works (Agyemang and Asiedu, 2013). When contractors reinvest profits and capital into new projects or assests, they inadvertently raise the risk of facing financial distress and project delays successively. This is because 'locked-up cash' is a major contributor to company failure. The onus therefore rests upon construction managers to control and anticipate the financial situation of projects and its impact upon cash flow during the tendering and post contract stage.

\section{Conclusion}

Addressing the underlining financial distress factors militating against SMEs firms in the construction industry will ensure firms' survival; in turn, this provides nations with the industrial 
capacity to boost economic growth through infrastructure development and GDP growth. This study completed a synthesis of literature to identify factors that cause financial distress. Data collected on these factors via a questionnaire survey instrument was then interpreted via thematic component groupings emanating from factor analysis. These issues include: i) payment; ii) project financing; iii) cash flow; iv) economic; v) political influence; and vi) cost control issues. A conceptual model that emerged from the analysis reveals how exogenous and endogenous environments (and components within these) can manifest as financial distress. Understanding the relationships between factors and environments is crucial to the avoidance of future delays and financial distress, and importantly, the development of long term solutions to the infrastructure crisis confronting developing nations.

The study's findings will be beneficial to managers of highway construction firms by providing them with the requisite information needed to guard against factors uncovered. This paper, may also initiate discussion among government policy makers (responsible for the management of highway construction projects in most developing countries) on the development of appropriate project and business management systems, processes and tools that mitigate underlying causes of financial distress. Future work is however required to explore pathogenic causes of project delays when measured against a country's level of economic activity - such work will expand the geographical use and application of this research. 


\section{REFERENCES}

Agyemang, B. E., and Asiedu, M.K. (2013) The Relationship Between Working Capital Management and Profitability of Listed Manufacturing Companies in Ghana, International Journal of Business and Social Research (IJBSR), Vol.3, No.2, pp. 25-34.

Ahadzie, D.K., Proverbs, D.G. and Olomolaiye, P.O. (2007) Critical Success Criteria For Mass Housing Building Projects in Developing Countries, International Journal of Project Management, Vol. 25, No. 2, pp. 1-13.

Amoatey, C.T., Ameyaw, T.A., Adaku, E., and Famiyeh, S. (2015) Analysing Delay Causes and Effects in Ghanaian State Housing Construction Projects, International Journal of Managing Projects in Business, Vol. 8, No. 1 pp. 198 - 214

Ameriks, J., Caplin, A., and Leahy, J. (2003) Wealth Accumulation and the Propensity to Plan. The Quarterly Journal of Economics, Vol. 118, No. 3, pp. 1023-1047.

Anaman, K.A. (2006) What Factors Have Influenced Economic Growth In Ghana?, IEA Ghana Policy Analysis, Vol.2 No.2, pp1-13. Available via: ieagh.org/wpcontent/uploads/2014/07/pol-ana-v2-n2.pdf [Accessed: July, 2015].

Badu, E., and Owusu-Manu, D. (2011) An Overview of Construction Activities in Kumasi: In The Future of the Tree-Towards Development and Growth. Ed. Kwasi Kwafo Adarkwa, 1st Edition, pp. 270-289.

Bondinuba, F.K. (2012). Exploring the Challenges and Barriers in Accessing Financial Facilities by Small and Medium Construction Firms in Ghana, Civil and Environmental Research, Vol. 2, No.6, pp. 25-35.

Bowers, J., and Alireza Khorakian, A. (2014) Integrating Risk Management in the Innovation Project, European Journal of Innovation Management, Vol. 17, No. 1 pp. 25 - 40. 
Brand, M.C., and Davenport, P. (2012) Adjudication in Australia, International Journal of Law in the Built Environment, Vol. 4, No. 3 pp. 189 - 202.

Chowdhury, R.H., and Min Maung, M. (2013) Corporate Entrepreneurship and Debt Financing: Evidence from the GCC Countries, International Journal of Managerial Finance, Vol. 9, No. 4, pp. $294-313$

Cilensek, R. (1991) Understanding Contractor Overhead, Cost Engineering (AACE), Vol. 33, No. 12, pp. 21-31.

Comrey, A. L. and Lee, H. B. (1992) A First Course in Factor Analysis, Hillsdale, NJ: Erlbaum.

Crosthwaite, D. (2000) The Global Construction Market: a Cross Sectional Analysis, Construction Management and Economics, Vol. 18, No.1, pp. 619-627.

Cotterman, J.D. (2014) Calculating Profitability. Altman Weil, Inc., Newtown Square, PA, USA. Available via: www.altmanweil.com/...62858eb1-14c1-4b32-b748-bbe9c4e70bd7_do. [Accessed May, 2015]

De Gregorio, J. (2015) From Rapid Recovery to Slowdown: Why Recent Economic Growth in Latin America Has Been Slow. Number PB 15 - 6 Petersen Institute for International Economics. Available via: www.iie.com/publications/pb/pb15-6.pdf. [Accessed: July, 2015].

Emuze, F., and Smallwood, J.J. (2014) Collaborative Working in South African Construction: Contractors' Perspectives, Journal of Engineering, Design and Technology, Vol. 12, No. 3 pp. $294-306$

Field, A. (2005) Discovering Statistics, Using SPSS for Windows, London: Sage Publications. 
Fisher, J., Gilsinan, J., Islam, M., and Seitz, M. (2014) Who Were the Winners and Losers in the Financial Crisis of 2008: It Depends, Journal of Financial Crime, Vol. 21, No. 4, pp. 447 460.

Shanks, M. (2012) Milgram Revisited, Journal of Global Responsibility, Vol. 3, No.1, pp. 66 - 82.

Foster, V. and Briceño-Garmendia, C. (2009) Africa's Infrastructure: A Time for Transformation and a of Summary Overview. Available via: http://www.emergingmarketsforum.org/papers/pdf/2009-EMF-Africa-Foster-Briceno

Garmendia_Infrastructure_Transf.pdf [Accessed: February, 2014].

Hackett, C. (2014) The Rebirth of Dependence - Offering an Alternative Understanding of Financial Crisis, International Journal of Law and Management, Vol. 56, No. 2, pp. 121 135

Javier, R., and Herminio, R. (2014) Global Real Estate Mutual Funds: Regional Exposure and Forecasting Skill, International Journal of Managerial Finance, Vol. 10, No. 2, pp. 168 - 179

Karl, M. (2002). Economic Distress, Financial Distress and Dynamic Liquidation, Journal of Finance, Vol. LVII , No. 1, pp. 135-168.

Kayed, R.N. (2012) The Entrepreneurial Role of Profit-and-Loss Sharing Modes of Finance: Theory and Practice, International Journal of Islamic and Middle Eastern Finance and Management, Vol. 5, No. 3 pp. 203 - 228

Korley, M. (2014) Exploring Procurement Risk Associated With Contract Closeout: Procurement Entities Perspective. Unpublished Master Dissertation. Department of Building Technology, KNUST. Available via: www.ir.knust.edu.gh/bitstream/123456789/.../MAYNARD\%20KORLEY.pdf. [Accessed: May, 2015]. 
Leathers, C.G., Raines, J.P., and Richardson-Bono, H.R. (2015) Natural Experiments and DebtDriven Financial Crises: Mortgage Finance Booms in the 1920s and 2000s, International Journal of Social Economics, Vol. 42, No. 4 pp. 340 - 355

Liozu, S., Hinterhuber, A., and Somers, T. (2014) Pricing Capabilities: The Design, Development, and Validation of a Scale, Management Decision, Vol. 52, No. 1 pp. 144-158

Lu, I.-F., Guo, S.-J., and Pan, Y.-J. (2011) Construction Project Management and Insurance Program for Taiwan High Speed Rail Project, Leadership and Management in Engineering, ASCE, Vol. 11, No. 1, pp. 45-56.

Maksimovic, V and Phillips, G.( 1998) Asset Efficiency and Reallocation Decisions of Bankrupt Firms, Journal of Finance, Vol. 53, No. 1, pp. 1495-1532.

Marchais-Roubelat, A. (2012) Contracts to Frame Sustainable Futures, Society and Business Review, Vol. 7, No. 1 pp. 50 - 64

Mathur, G., Jugdev, K., and Fung, T.S. (2013) Project Management Assets and Project Management Performance Outcomes: Exploratory Factor Analysis, Management Research Review, Vol. 36, No. 2, pp. 112-135.

Memba, F. and Job, A.N. (2013) Causes of Financial Distress: A Survey of Firms Funded by Industrial and Commercial Development Corporation in Kenya, Interdisciplinary Journal of Contemporary Research in Business, Vol. 4, No. 12, pp. 1171-1185.

Mossman, C. E., Bell, G.G., Swartz, L.M. and Turtle, H. (1998) An Empirical Comparison of Bankruptcy Models. Financial Review Vol. 33, No. 2, pp 35-54.

Ndekugri, I., Daeche, H., and Zhou, D. (2013) The Project Insurance Option In Infrastructure Procurement, Engineering, Construction and Architectural Management, Vol. 20, No. 3, pp. $267-289$. 
Odeyinka, H.A. and Yusif, A. (1987) The Causes and Effects of Construction Delays on Completion Cost of Housing Project in Nigeria. Journal of Financial Management and Property Construction, Vol. 2, No.3, pp 31-44.

Orobia, L.A., Byabashaija, W., Munene, J.C., Sejjaaka, S.K., Musinguzi,D. (2013) How Do Small Business Owners Manage Working Capital In An Emerging Economy?", Qualitative Research in Accounting \& Management, Vol. 10, No. 2, pp. 127 - 143.

Sá, C., Martins, A., and Gomes, C. (2014) The Influence of Demographic Factors and Risk Aversion on Tax Morale: A Multi-group Analysis, European Journal of Research on Education, Vol. 2, No. 2, pp. 82-93.

Salleh, M.F., and Ahmad, A. (2012) Political Influence on Economic Decision-Making in Government-Owned Companies: From the Perspectives of Key Players, African Journal of Business Management, Vol. 6, No.7, pp. 2716-2726.

Shah, A., and Whalley, J. (1990) Tax Incidence Analysis of Developing Countries: An Alternative View, World Bank Economic Review, Vol. 5, No.1, pp. 533-552.

Tanco,M., Jurburg, D., and Escuder, M. (2015) Main Difficulties Hindering Supply Chain Performance: An Exploratory Analysis at Uruguayan SMEs, Supply Chain Management: An International Journal, Vol. 20, No. 1, pp.11-23.

Tsai, C-F. (2014) Combining Cluster Analysis with Classifier Ensembles to Predict Financial Distress, Information Fusion, Vol. 16, No.1, pp. 46-58.

Wells, J. (2007) Informality in the Construction Industry in Developing Countries, Construction Management and Economics, Vol. 25, No.1, pp. 87-93.

Yeoh, P. (2012) Bribery Act 2010: Implications for Regulated Firms, Journal of Financial Regulation and Compliance, Vol. 20, No. 3, pp. 264 - 277. 
Zack, J.G. (1993) Claimanship: Current Prospective, Journal of Construction Engineering Management, Vol. 119, No.34, pp. 481-497. 
Figure 1 - Financial Risk Triggers

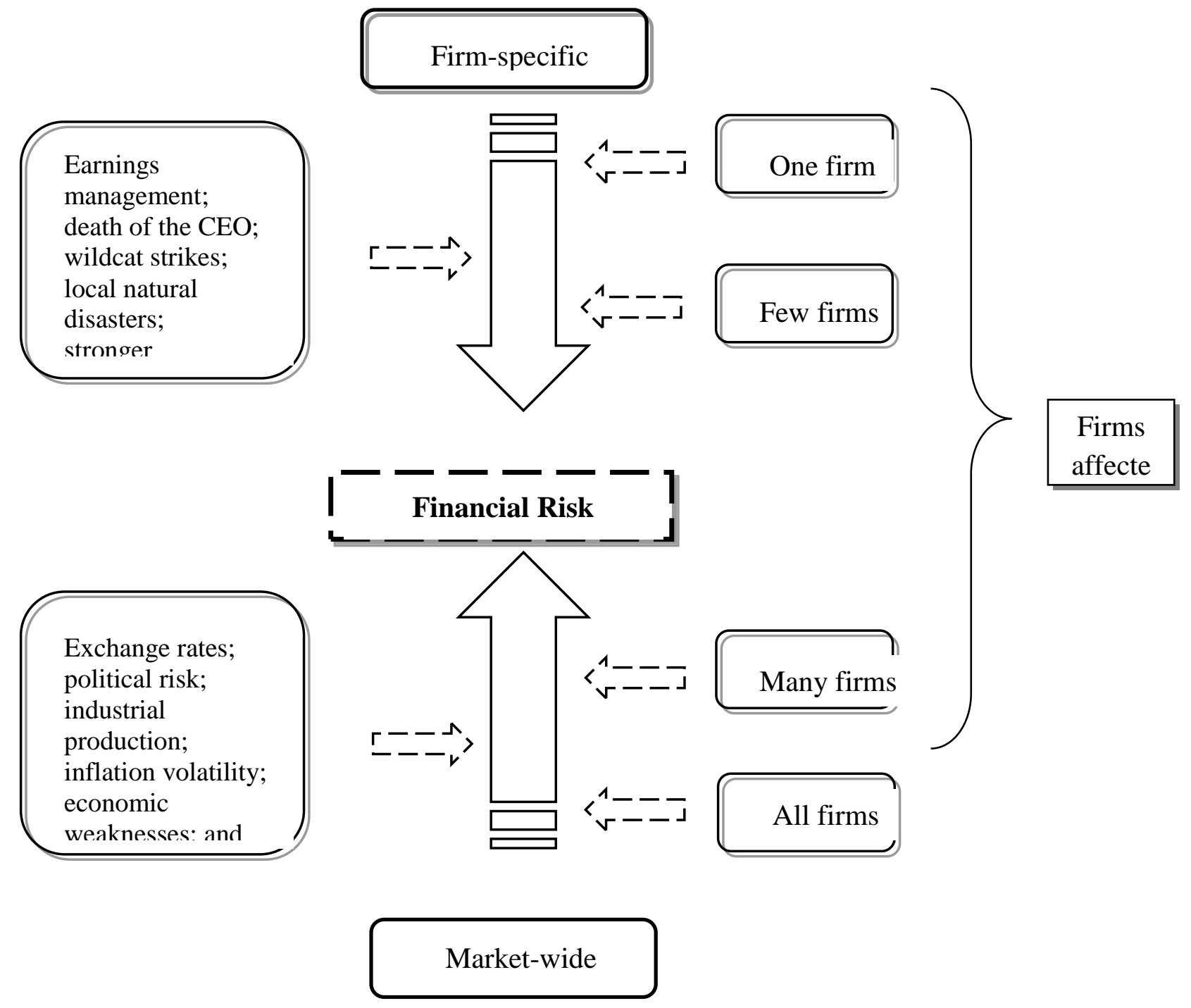

Adapted from Outecheva (2007) 


\begin{tabular}{|c|c|c|}
\hline FDR Factors & Description & Reference \\
\hline 1. Client's poor financial and business management & The inability to efficiently control and monitor budgetary and business activities. & Orobia et al., 2013 \\
\hline 2. High overhead expenses & Compensations in the form of salaries, bonuses and benefits associated with payroll & Cotterman, 2014 \\
\hline 3. Contractor's invalid claim & Attempting to acquire rewards for works not duly executed & Korley, 2014 \\
\hline 4. Withhold of payment certificates & The tendency of not releasing payment documents to the contractor promptly & Marchais-Roubelat, 2012 \\
\hline 5. Bureaucracy in honouring payment certificates & Official bottlenecks delaying payment to contractors & Ndekugri et al., 2013 \\
\hline 6. High insurance cost & Expenses incurred during indemnification for projects & Lu et al., 2011 \\
\hline 7. High tax allocations & Government charges on profits for development related projects & Shah and Whalley, 1990 \\
\hline 8. Divulging funds & Releasing monies without authority & Brand and Davenport, 2012 \\
\hline 9. Fraudulent practices by employees & Illegal actions of individuals in the employ of the firms & Yeoh, 2012 \\
\hline 10. Capital lockup & Investment of financial resources in a manner that they cannot have alternative uses & Hackett, 2014 \\
\hline $\begin{array}{l}\text { 11. Inaccuracy in valuation for work done by } \\
\text { consultants }\end{array}$ & Assigning wrong values to works executed by project professionals & Amoatey et al., 2015 \\
\hline 12. Unstable inflation rate & Erratic price levels of goods and services & Liozu et al., 2013 \\
\hline 13. High interest rate chargeable on loans & $\begin{array}{l}\text { Amounts charged as rewards for financial institutions for providing services to } \\
\text { clients }\end{array}$ & Kayed, 2012 \\
\hline 14. Underestimation of project cost & Providing expenses less than the actual expenditures of the project & $\begin{array}{l}\text { Bowers and Khorakian, } \\
2014\end{array}$ \\
\hline $\begin{array}{l}\text { 15. Contractor handling many projects at the same } \\
\text { time }\end{array}$ & Contractor executing many works within a particular period of time & $\begin{array}{l}\text { Emuze and Smallwood, } \\
2014\end{array}$ \\
\hline 16. Lack of regular cash flow forecasting & Fluctuations in the flow of funds & Javier and Herminio, 2014 \\
\hline 17. Low markups / profit margins & Quoting less amount for profits and overheads & Fisher et al., 2014 \\
\hline $\begin{array}{l}\text { 18. Poor credit arrangement with creditors and } \\
\text { financiers }\end{array}$ & Inability to institute the requisite procedures for honouring debts & Shanks, 2012 \\
\hline 19. Difficulty in loan accessibility from financiers & Inability to secure financial assistance from financial institutions & $\begin{array}{l}\text { Chowdhury and Maung, } \\
2013\end{array}$ \\
\hline 20. Insolvency / liquidity & The inability of the firm to meet its debt obligation to creditors & Leathers et al., 2015 \\
\hline
\end{tabular}


Table 2 - Descriptive Statistics

\begin{tabular}{llcccc}
\hline Financial Distress Factors Critical to Project Delay & N & $\begin{array}{c}\text { Sample } \\
\text { Mean }\end{array}$ & $\begin{array}{c}\text { Std. } \\
\text { Error }\end{array}$ & $\begin{array}{c}\text { Std. } \\
\text { Deviation }\end{array}$ \\
\hline Client's poor financial and business management & 78 & 4.46 & 0.087 & 0.768 \\
2 High overhead expenses & 78 & 3.58 & 0.072 & 0.635 \\
3 Contractor's invalid claim & 78 & 3.55 & 0.104 & 0.921 \\
4 Withhold of payment by client & 78 & 3.71 & 0.069 & 0.605 \\
5 Bureaucracy in honouring payment certificate & 78 & 3.53 & 0.077 & 0.679 \\
6 High insurance costs & 78 & 3.76 & 0.107 & 0.942 \\
7 High tax allocation & 78 & 4.44 & 0.094 & 0.831 \\
8 Divulging funds & 78 & 4.00 & 0.102 & 0.897 \\
9 Fraudulent practices by employees & 78 & 4.08 & 0.103 & 0.908 \\
10 Capital lockup & 78 & 4.08 & 0.085 & 0.752 \\
11 Inaccuracy in valuation for work done by & & & & \\
consultants & 78 & 3.67 & 0.075 & 0.658 \\
12 Unstable inflation rate & 78 & 3.51 & 0.111 & 0.977 \\
13 High interest rate chargeable on loans & 78 & 3.56 & 0.119 & 0.988 \\
14 Underestimation of project cost & 78 & 3.47 & 0.907 & 0.801 \\
15 Contractor handling many projects at the same time & 78 & 3.83 & 0.080 & 0.710 \\
16 Lack of regular cash flow forecasting & 78 & 3.92 & 0.114 & 1.003 \\
17 Low markups / profit margins & 78 & 3.54 & 0.079 & 0.697 \\
18 Poor credit arrangement with creditors and & & & & \\
financiers & 78 & 3.49 & 0.121 & 1.066 \\
19 Difficulty in loan accessibility from financiers & 78 & 3.69 & 0.117 & 1.036 \\
20 Insolvency / liquidity & 78 & 3.23 & 0.121 & 1.068 \\
\hline
\end{tabular}


Table 3 - Test of Hypothesis using Chi-Square Test

\begin{tabular}{|c|c|c|c|c|}
\hline Financial Distress Factors & $\begin{array}{l}\text { Chi- } \\
\text { square }\end{array}$ & Df & P-values & Decision \\
\hline 1 Clients' poor financial and business management & $66.92 \mathrm{a}$ & 3 & 0.000 & Reject \\
\hline 2 High overhead expenses & $56.872 \mathrm{a}$ & 3 & 0.000 & Reject \\
\hline 3 Contractor's invalid claim & $35.333 \mathrm{a}$ & 3 & 0.000 & Reject \\
\hline 4 Withhold of payment certificates & $62.205 \mathrm{a}$ & 3 & 0.000 & Reject \\
\hline 5 Bureaucracy in honouring payment certificates & $31.000 \mathrm{~b}$ & 2 & 0.000 & Reject \\
\hline 6 High insurance cost & $17.897 \mathrm{a}$ & 3 & 0.000 & Reject \\
\hline 7 High tax allocations & $65.282 \mathrm{a}$ & 3 & 0.000 & Reject \\
\hline 8 Divulging funds & $26.923 a$ & 3 & 0.000 & Reject \\
\hline 9 Fraudulent practices by employees & $16.974 \mathrm{a}$ & 3 & 0.001 & Reject \\
\hline 10 Capital lockup & $16.000 \mathrm{~b}$ & 2 & 0.000 & Reject \\
\hline $\begin{array}{l}11 \text { Inaccuracy in valuation for work done by } \\
\text { consultants }\end{array}$ & $54.718 \mathrm{a}$ & 3 & 0.000 & Reject \\
\hline 12 Unstable inflation rate & $24.923 b$ & 2 & 0.000 & Reject \\
\hline 13 High interest rate chargeable on loans & $26.385 b$ & 2 & 0.000 & Reject \\
\hline 14 Underestimation of project cost & $28.538 \mathrm{c}$ & 4 & 0.000 & Reject \\
\hline $\begin{array}{l}15 \text { Contractor handling many projects at the same } \\
\text { time }\end{array}$ & $15.077 \mathrm{c}$ & 4 & 0.005 & Reject \\
\hline 16 Lack of regular cash flow forecasting & $44.051 \mathrm{a}$ & 3 & 0.000 & Reject \\
\hline 17 Low markups / profit margins & $49.282 \mathrm{a}$ & 3 & 0.000 & Reject \\
\hline $\begin{array}{l}18 \text { Poor credit arrangement with creditors and } \\
\text { financiers }\end{array}$ & $16.051 \mathrm{a}$ & 3 & 0.001 & Reject \\
\hline 19 Difficulty in loan accessibility from financiers & $17.897 \mathrm{a}$ & 3 & 0.000 & Reject \\
\hline 20 Insolvency / liquidity & $29.154 b$ & 2 & 0.000 & Reject \\
\hline
\end{tabular}




\begin{tabular}{llcc}
\hline FDR Causes of Project Delay & Initial & Extraction \\
\hline 1 & Client's poor financial and business management & 1.000 & .679 \\
2 & Contractor's invalid claim & 1.000 & .912 \\
3 & High overhead expenses & 1.000 & .424 \\
4 & Withhold of payment by client & 1.000 & .810 \\
5 & Bureaucracy in honouring payment certificate & 1.000 & .812 \\
6 & Budget allocation not made by client & 1.000 & .455 \\
7 & High tax allocation & 1.000 & .944 \\
8 & Divulging funds & 1.000 & .851 \\
9 & Fraudulent practices by employees & 1.000 & .564 \\
10 Capital lockup & 1.000 & .628 \\
11 & Inaccuracy in valuation for work done by consultants & 1.000 & .726 \\
12 & Unstable inflation rate & 1.000 & .917 \\
13 High interest rate chargeable on loans & 1.000 & .655 \\
14 & Underestimation of project cost & 1.000 & .676 \\
15 & Contractor handling many projects at the same time & 1.000 & .416 \\
16 & Lack of regular cash flow forecasting & 1.000 & .835 \\
17 & Low markups / profit margins & 1.000 & .636 \\
18 Poor credit arrangement with creditors and financiers & 1.000 & .716 \\
19 & Difficulty in loan accessibility from financiers & 1.000 & .821 \\
20 Insolvency / liquidity & 1.000 & .696 \\
\hline
\end{tabular}

Extraction Method: Principal Component Analysis. 
Table 5 - Total Variance Explained

\begin{tabular}{|c|c|c|c|c|c|c|c|c|c|}
\hline \multirow[b]{2}{*}{$\begin{array}{l}\text { Com- } \\
\text { ponent }\end{array}$} & \multicolumn{3}{|c|}{ Initial Eigenvalues } & \multicolumn{3}{|c|}{$\begin{array}{l}\text { Extraction Sums of Squared } \\
\text { Loadings }\end{array}$} & \multicolumn{3}{|c|}{ Rotation Sums of Squared Loadings } \\
\hline & Total & $\begin{array}{l}\% \\
\text { Variance }\end{array}$ & $\begin{array}{l}\text { of Cumulative } \\
\%\end{array}$ & Total & $\begin{array}{l}\% \\
\text { Variance }\end{array}$ & $\begin{array}{l}\text { of Cumulative } \\
\%\end{array}$ & Total & $\%$ of Variance & Cumulative \% \\
\hline 1 & 4.277 & 21.387 & 21.387 & 4.277 & 21.387 & 21.387 & 3.794 & 18.970 & 18.970 \\
\hline 2 & 3.081 & 15.405 & 36.792 & 3.081 & 15.405 & 36.792 & 2.914 & 14.570 & 33.540 \\
\hline 3 & 2.480 & 12.398 & 49.190 & 2.480 & 12.398 & 49.190 & 2.598 & 12.988 & 46.528 \\
\hline 4 & 1.909 & 9.547 & 58.737 & 1.909 & 9.547 & 58.737 & 2.054 & 10.272 & 56.801 \\
\hline 5 & 1.226 & 6.129 & 64.866 & 1.226 & 6.129 & 64.866 & 1.411 & 7.056 & 63.857 \\
\hline 6 & 1.199 & 5.993 & 70.860 & 1.199 & 5.993 & 70.860 & 1.401 & 7.003 & 70.860 \\
\hline 7 & .984 & 4.918 & 75.778 & & & & & & \\
\hline 8 & .948 & 4.742 & 80.520 & & & & & & \\
\hline 9 & .725 & 3.623 & 84.142 & & & & & & \\
\hline 10 & .588 & 2.942 & 87.085 & & & & & & \\
\hline 11 & .494 & 2.469 & 89.554 & & & & & & \\
\hline 12 & .467 & 2.333 & 91.887 & & & & & & \\
\hline 13 & .376 & 1.879 & 93.766 & & & & & & \\
\hline 14 & .333 & 1.663 & 95.429 & & & & & & \\
\hline 15 & .263 & 1.313 & 96.742 & & & & & & \\
\hline 16 & .221 & 1.107 & 97.849 & & & & & & \\
\hline 17 & .202 & 1.010 & 98.859 & & & & & & \\
\hline 18 & .093 & .464 & 99.323 & & & & & & \\
\hline 19 & .069 & .347 & 99.670 & & & & & & \\
\hline 20 & .066 & .330 & 100.000 & & & & & & \\
\hline
\end{tabular}


53 Figure 2 - Scree Plot for the FDR Variables

\section{Scree Plot}

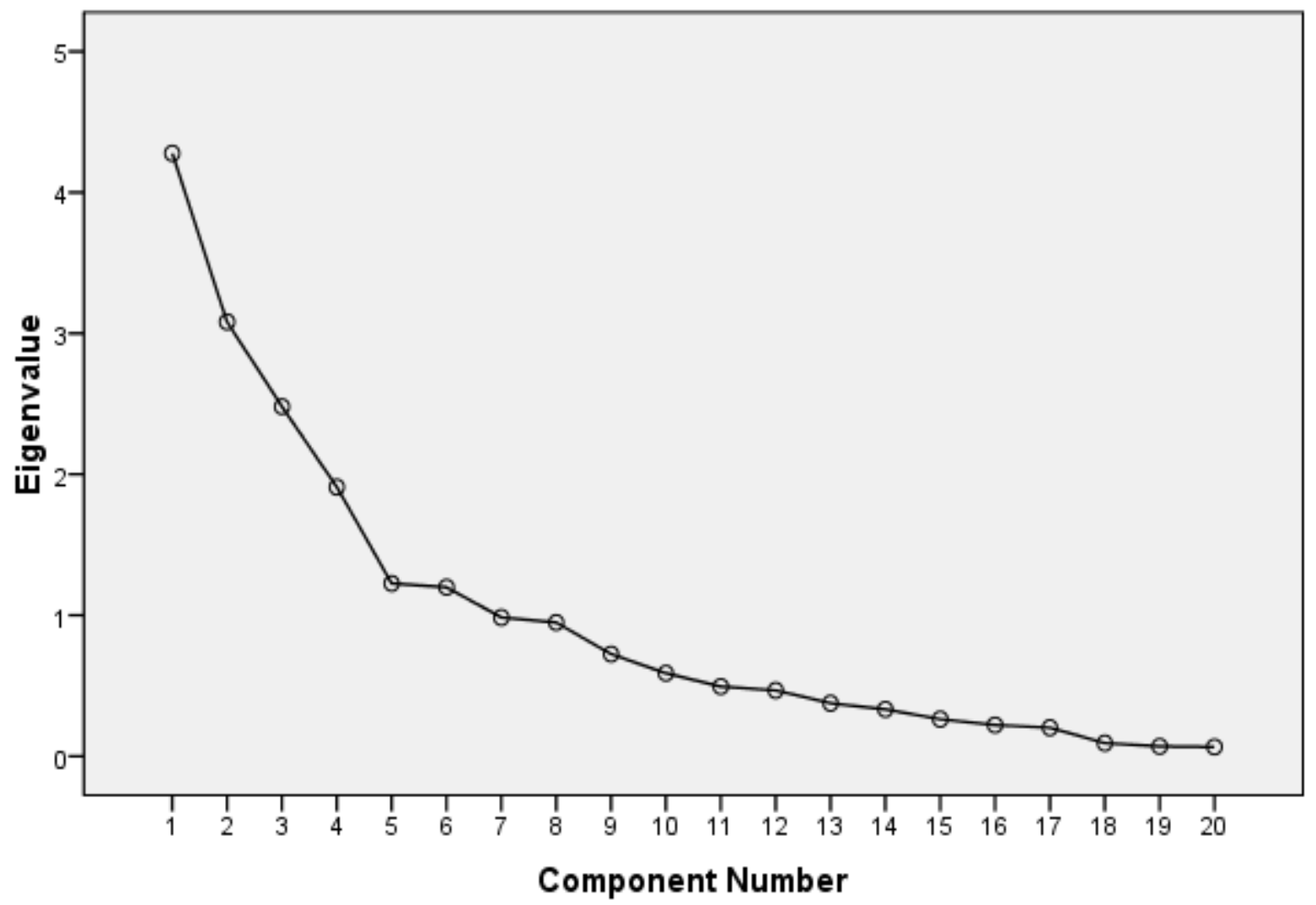

54

55 


\begin{tabular}{|c|c|c|c|c|c|c|c|}
\hline & & & & Comp & onent & & \\
\hline & & 1 & 2 & 3 & 4 & 5 & 6 \\
\hline 1 & Client's poor financial and Business management & & & .578 & & & \\
\hline 2 & Contractor's invalid claim & .942 & & & & & \\
\hline 3 & High overhead expenses & & & & & & .540 \\
\hline 4 & Withhold of payment by client & .891 & & & & & \\
\hline 5 & Bureaucracy in honouring payment certificate & .884 & & & & & \\
\hline 6 & Budget allocation not made by client & & & & & -.596 & \\
\hline 7 & High tax allocation & & & & .964 & & \\
\hline 8 & Divulging funds & & & .866 & & & \\
\hline 9 & Fraudulent practices by employees & & & .722 & & & \\
\hline 10 & Capital lockup & & & & & & .784 \\
\hline 11 & Inaccuracy in valuation for work done by consultants & .848 & & & & & \\
\hline 12 & Unstable inflation rate & & & & .941 & & \\
\hline 13 & High interest rate chargeable on loans & & .798 & & & & \\
\hline 14 & Underestimation of project cost & .657 & & & & & \\
\hline 15 & Contractor handling many projects at the same time & & & & & .555 & \\
\hline 16 & Lack of regular cash flow forecasting & & & .882 & & & \\
\hline 17 & Low markups / profit margins & & & & & .662 & \\
\hline 18 & Poor credit arrangement with creditors and financiers & & .841 & & & & \\
\hline 19 & Difficulty in loan accessibility from financiers & & .887 & & & & \\
\hline 20 & Insolvency / liquidity & & .810 & & & & \\
\hline
\end{tabular}

Extraction Method: Principal Component Analysis.

Rotation Method: Varimax with Kaiser Normalization. 
$74 \quad$ Table 7: Profile of Respondent Firms

\begin{tabular}{lcccc}
\hline & & & & Cumulative \\
A. Legal Status of firms & Frequency & Percent & Valid Percent & Percent \\
\hline 1. Sole proprietorship / enterprise & 22 & 28.2 & 28.2 & 28.2 \\
2. Partnership & 18 & 23.1 & 23.1 & 51.3 \\
3. Limited liability Company & 38 & 48.7 & 48.7 & 100.0 \\
Total & 78 & 100.0 & 100.0 & \\
\hline
\end{tabular}

B. Work Experience of Firms

\begin{tabular}{lcccc}
\hline 1. up to 5 years & 15 & 19.2 & 19.2 & 19.2 \\
2. 6-10 years & 27 & 34.6 & 34.6 & 53.8 \\
3. 11-15 years & 23 & 29.5 & 29.5 & 83.3 \\
4. 16-20 years & 8 & 10.3 & 10.3 & 93.6 \\
5. Over 20 years & 5 & 6.4 & 6.4 & $\mathbf{1 0 0 . 0}$ \\
\hline Total & $\mathbf{7 8}$ & $\mathbf{1 0 0 . 0}$ & $\mathbf{1 0 0 . 0}$ & \\
\hline
\end{tabular}

75

76 
77 Figure 3 - Exogenous and Endogenous Components Impact upon Contractor's Financial Distress

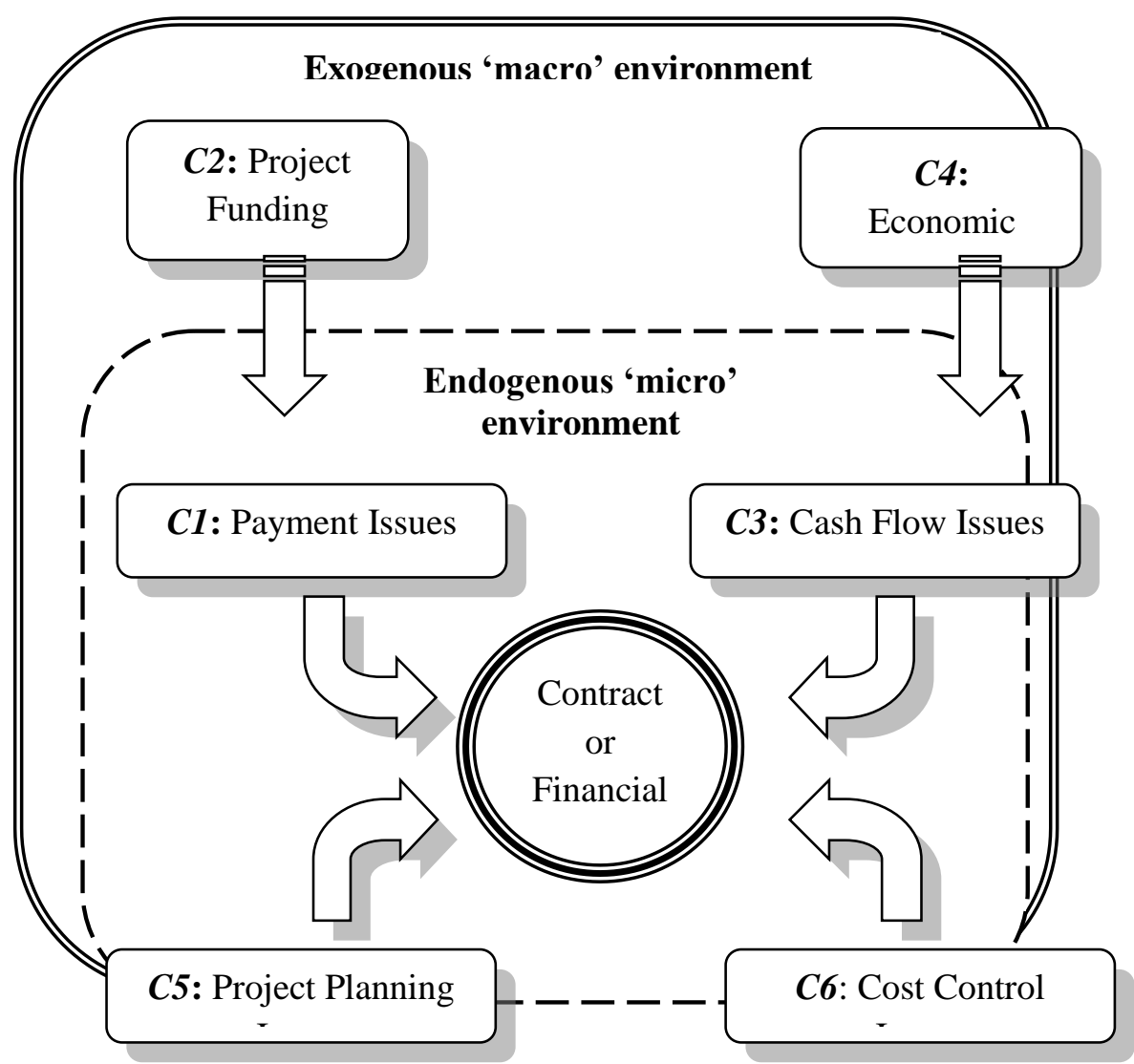

